\title{
Communities, universities and ethnicity: A conversation from Imagine: Connecting Communities Through Research
}

\author{
Milton Brown - Kirklees Local TV, Huddersfield, UK \\ Paul Ward* - Edge Hill University, UK
}

\begin{abstract}
Imagine: Connecting Communities Through Research was a large five-year project in the Connected Communities programme using methodologies of co-production to explore imagining different futures with community groups. This article, which takes the form of a conversation, offers the perspectives of two participants in Imagine to discuss how community organizations and communities work together and the impact of ethnic discrimination and disparity in universities. We set the conversation in the broader context of global discussions of knowledge production and power relationships. We consider how universities, as large institutions, often create difficulties for smaller community organizations by focusing on their own interests. We address power and decision-making in Imagine, especially in relation to ethnicity. We seek to think about what needs to be done, both at strategic levels in universities and on a personal level, to tilt the balance of benefit towards communities in collaborative relationships with higher education institutions.
\end{abstract}

Keywords: university-community relationships; collaborative research; ethnicity; knowledge

\section{Key messages}

- Co-produced research and collaborative methods provide substantial opportunities for community organizations to work with universities to contribute to knowledge production to underpin social change.

- The size of universities, as institutions with significant resources and finance, and a desire to maintain them, gives them disproportionate power in collaborations with smaller community groups at institutional and personal levels. This is exacerbated by the lack of ethnic diversity in universities.

- Universities must acknowledge the impediments they place in the way of community organizations. This includes discrimination in recruitment, promotion and attainment. Academic researchers need to act to lessen the obstacles faced by community organizations with which they work.

The 'participatory turn' in some university research, in which sets of knowledge from inside and outside universities are brought together (Facer and Enright, 2016; Nolan et al., 2007), raises questions about how universities work with community organizations, particularly because of structural ethnic inequalities in British higher education. In this 
essay, we seek to explore some of these parallel issues within a large British researchcouncil-funded grant called Imagine: Connecting Communities Through Research (www.imaginecommunity.org.uk; UK Research and Innovation, 2018).

The Economic and Social Research Council funded the five-year project to explore the contexts in which people become engaged in civic life. The Imagine project involved academics working with a range of people in different roles, including artists, museum educators, youth workers, community workers, activists, residents, teachers, young people and policymakers. It involved disciplines including history, social sciences, arts practice, architecture and literary theory. It emphasized the co-production of research, drawing on the Connected Communities programme of which it was part. We wanted to actively work together to produce collaborative research in which different kinds of knowledge were valued. It involved a conscious awareness on the part of all coresearchers that some people may have more experience and expertise in different areas, and that working together produces better knowledge than academic research alone. Part of the project involved working with and alongside children, young people, families and adults exposed to social disadvantage and inequalities. Another part explored histories of urban community development programmes, and elsewhere we worked with Black, Asian and minority ethnic people to explore how knowledge is created to inform identity and policy. It was in this part that we, the discussants in this article, were involved. We used university and community resources and expertise to organize or contribute to Black history events with the History Department at the University of Huddersfield, working with a local internet television station across a range of their activities in documenting the local community.

We write the article from two different perspectives. As co-researchers, we have been working together since 2013. Milton Brown is a community activist, filmmaker and academic. In 2010, he founded an organization called Kirklees Local TV (http://kirkleeslocaltv.com) as a social enterprise to document the local community around Huddersfield and Dewsbury through film. Milton started a PhD, which explores histories of the African-Caribbean experience in Britain since the 1960s, after meeting Paul Ward, a history professor at Edge Hill University, at an event that Kirklees Local TV were filming. Milton's PhD explores the navigation of social policy such as 'race relations' and identity and its impact on communities. This has led Milton to think about how university leaders often fail to understand the communities in which they are located. Paul is a career academic - a professor of modern British history - with some history of political activism and working with communities on historical projects, with his main research focus being on national identities in the United Kingdom since the nineteenth century. For five years, he was head of a department at Huddersfield with an academic staff of about fifty and a gross annual budget of about $f 3$ million (he is now head of a similar department at Edge Hill University). It is relevant that Milton is of Black African descent and Paul is White British. They have worked together in the context of the development of methodologies of the co-production of research, inspired by Imagine.

Imagine, and Milton and Paul's collaborative research, can be set in a wider research context. There are the hundreds of projects funded by the Arts and Humanities Research Council (AHRC) through the Connected Communities programme, which use an enormous variety of means and methods 'to help us understand the changing nature of communities in their historical and cultural contexts and the role of communities in sustaining and enhancing our quality of life' (Connected Communities, 2016). It includes moves towards engaged scholarship, community-university partnerships and civic universities. 
Imagine was, therefore, part of a whole series of global initiatives responding to imbalances of power over knowledge that include the knowledge democracy movement, which:

acknowledges the importance of the existence of multiple epistemologies or ways of knowing such as organic, spiritual and land-based systems, frameworks arising from our social movements, and the knowledge of the marginalized or excluded everywhere, or what is sometimes referred to as subaltern knowledge. (Hall and Tandon, 2015: n.p.)

It is linked to indigenous forms of knowledge, such as those expressed in Linda Tuhiwai Smith's Decolonising Methodologies: Research and indigenous peoples (2012). Boaventura de Sousa Santos (2016: 19) has popularized the concept of 'epistemologies of the south' linked to populations in the northern hemisphere 'in the form of excluded, silenced and marginalized populations, such as undocumented immigrants, the unemployed, ethnic or religious minorities, and victims of sexism, homophobia, racism and islamophobia'. The appointment of the UNESCO Chair in Community-based Research aims at 'building community-based research capacity in the global South and the Excluded North to produce participatory knowledge that is locally contextualized and community driven' (Partnerships for the SDGs, 2017: n.p.). The post, held by Budd Hall and Rajesh Tandon, is another means to harness 'the power and potential of community and higher education-based scholars and activists working together in the co-creation of transformative knowledge' (Hall et al., 2013: n.p.). These global knowledge movements are played out at a local level through relationships in community-university research partnerships such as Imagine, and in the personal relationships of researchers such as Milton and Paul, which enable us to discuss some of the hard questions in relationships in which there is an imbalance of power, in this case due to Paul's employment by a major institution with substantial resources.

In this essay, Milton poses a series of observations and questions about Imagine, which have wider implications for how power operates, how knowledge is contained within institutional structures, and for understanding ethnicity and higher education in Britain. (For another perspective on Imagine, see Rasool, 2017.) Paul seeks to respond to some of Milton's questions and concerns, and they seek to come to some joint understanding of potential ways forward for future working.

We worked on and wrote this essay as a dialogic conversation. Milton first provides a brief overview of how he understands Imagine. Second, he gives his view of what he has learnt from his experience of working within and for the Imagine project as a community partner. Finally, he gives his opinion regarding what his concerns are for universities working with voluntary sector organizations, social enterprises and community-based organizations in relation to organizational values, leadership and authority. He raises a series of questions about working with universities as a social enterprise within Imagine, and especially working with the University of Huddersfield. Paul, one of the lead co-investigators on Imagine, makes a preliminary response to these questions, and we seek, in a very provisional way, to draw some conclusions about how universities and community-based organizations need to develop successful working and sustainable relationships that begin to address issues of ethnic diversity and inclusion in universities and research projects. By sustainable relationships, we mean moving beyond unconnected and separate projects, towards community knowledge being an integral part of research being undertaken in universities. This might include a range of relationships relating to research-led teaching, for example, 
in which community partners are recognized as playing a role in a variety of aspects of university life, rather than being limited to 'impact' as defined in the Research Excellence Framework (REF), which assesses the quality of university research every six years or so. The REF defines 'impact' as research that has 'an effect on, change or benefit to the economy, society, culture, public policy or services, health, the environment or quality of life, beyond academia' (HEFCE, 2016: n.p.). This continues to place the emphasis on what universities do - their impact - rather than shared knowledge created by the agency of research partnerships. The universities decide what counts as 'impact' driven by the REF imperative, rather than by what communities define as their needs. (For critiques of REF impact, see Shortt, 2016 and Pace, 2018.) In this essay, Milton raises a series of issues and Paul seeks to respond. Both of us write as individuals, but as individuals embedded in different contexts - one in the community and the other in the academy.

\section{Milton and his role in Imagine}

I have been part of the Imagine project for approximately three years. I have attended 12 Imagine conferences and retreats, observing and participating in discussions on the research questions posed by the project, especially relating to how the landscape of community research is being transformed by developments in the research methodologies employed in the arts and humanities and social sciences, particularly the promotion of co-produced research and creative, collaborative, participatory and inclusive methods. On five occasions, I was invited as a keynote speaker, presenting on the importance of co-production, community partnerships and the mutual benefits for universities and community organizations. I also presented to the Office for Civil Society in the Department for Digital, Media, Culture and Sport (in 2018), and met with civil servants from the Ministry of Housing, Communities and Local Government and the Cabinet Office.

Everyone I have met throughout the Imagine conferences, workshops and meetings across the country as part of the Connected Communities programme has been committed, inspiring and enthusiastic during processes of addressing the key research questions and challenges that the Imagine project stimulates. Involving about ten universities and thirty community partners, Imagine is very complex. I was privileged to produce a 20-minute video production trying to capture the essence of the project at its halfway stage in 2015/16. I was invited to make the film as a community film-maker. I visited other community partners from across Imagine, and gathered film footage and photographs to be included. I interviewed the four lead co-investigators. The film was co-produced, in that everyone had a say in how their organizations wanted to be presented in the final film. Gaining consensus among more than 25 organizations created a few problems, but strong leadership brought all parties concerned to a respectful agreement. I was able to experience the ethics and emotions, and the different organizational, structural and cultural values contributing to the Imagine process (Kirklees Local Television, 2016). Even so, I have not been able to attain a full understanding of the project, because I have been working beneath the surface, unable to see all of Imagine as its lead co-investigators are able to do. I have been involved in operational parts of the project, but not its strategic direction.

The consistency of approach has been one of determination and enthusiasm, and indeed celebration of the work that Imagine has achieved as a whole. I have certainly experienced this excitement, and have enjoyed a stimulating and rich environment for learning and networking when attending the Imagine project (and 
Connected Communities) events. As a community partner, I feel that this environment is essential for personal and professional development around community relations and academia.

I have been witness to the excellent leadership styles of Imagine's principal investigator, Professor Kate Pahl (who was then at the University of Sheffield), and its co-investigators, Professor Angie Hart (University of Brighton), Professor Sarah Banks (Durham University) and Professor Paul Ward (University of Huddersfield). Although different, their leadership styles complement each other very well, and we cannot deny the positive impact that Imagine has had on most of those who have been associated with it. The needs of Imagine as a funded research project and the needs of the community groups involved were mutual, and continuous discussion at conferences, workshops and other events meant that we worked together towards jointly agreed goals and outcomes. New ideas, friends, colleagues and partnerships have emerged and will continue to grow from participating in the Imagine project experience.

\section{Milton: My personal experience}

I have learnt how multiple organizations from both public and voluntary sectors can coexist in the same space and produce some exciting and worthwhile results. The administration of the Imagine project has been exceptional. Keeping a project as large and as complex as Imagine on track is remarkable, and I truly value the importance of strong transformational, bureaucratic, charismatic, people-oriented leadership, and good administration and communication. I have learnt new ideas about how to project-manage strategically and operationally. Being around enthusiastic academics and individuals from various walks of life has certainly enriched my appetite to learn and to further investigate how this learning can be transferred to others and applied within my own social enterprise project.

From my perspective, a university's value base and principles link to the fact that it is a business, which provides education, but that must at the same time make money in order to survive. This conflicts with the values of social enterprises and community organizations, which have a variety of purposes and income sources, and which are far less secure and often dwarfed by the size of universities. For the community organizations, people, social values and civic engagement are our core business, rather than making money, which is the means to the end and not the end in itself.

\section{Paul: The role of universities}

It is good to hear the positive impact that being involved in Imagine had on you through your appetite to learn and to think about how to run creative projects. Across Imagine we have seen personal development alongside professional development. You know, for example, that several community partners have begun university courses, including $\mathrm{PhDs}$, and others have developed skills and contacts with a variety of policymakers. Imagine transformed my practice as a historian - making me think about how history is not only about the past but about the future as well.

However, I recognize the tensions as well as the opportunities. Your final point about universities and their function in society is interesting. There are a variety of ways of making money, and universities recruit students and seek to secure other external funding through research and enterprise. The balance between these tasks varies - and there are people critiquing the neo-liberal university approach that sees making money as the key measure of success. There is the idea of the civic university 
recently outlined by George Fallis (2014: 6), who suggests that: 'A civic university is a crucial institution of civil society in a democracy, an alternative centre of authority and a counterweight to government and business.' Similarly, John Goddard (2009: 5) argues that the civic university:

... engages as a whole with its surroundings, not piecemeal; it partners with other universities and colleges; and it is managed in a way that ensures it participates fully in the region of which it forms part. While it operates on a global scale, it realises that its location helps form its identity and provides opportunities for it to grow and help others, including individual learners, businesses and public institutions, to do so too.

Henry A. Giroux (2013: n.p.), in particular, appeals to me in his argument that:

If educators are to function as public intellectuals, they need to listen to young people who are producing a new language in order to talk about inequality and power relations, attempting to create alternative democratic public spaces, rethinking the very nature of politics, and asking serious questions about what democracy is and why it no longer exists in many neoliberal societies.

I think this is what Imagine was trying to do - to create alternative democratic spaces that countered the drift of universities towards operating as businesses with their own objectives in mind, rather than as a space where they could service the communities in which they are located. The four key universities in Imagine are very different - two Russell Group (elite) universities and two former polytechnics that became universities in 1992. The ways in which they work are different. Huddersfield, for example, sees itself as entrepreneurial and engaged with businesses through user-inspired research. Brighton champions community-university partnerships. Sheffield describes itself as a civic university. Durham calls itself 'A world top 100 university'. Universities therefore share many values but also differ on what they think they contribute to society. I can see how this complexity makes it difficult for small and medium-size organizations operating in different contexts to make sense of the universities located in their region, and that they therefore find it difficult to navigate them. And it is rare for universities to seek to make things easier.

\section{Milton: University and community values}

Irrespective of the model, universities must make money to survive, and the community is too often seen as being in a supporting role to this end, rather than as being integral to the university's business. The community base and social enterprise organization's value basis is essentially centred on people; in this manner, there is a heavy reliance on volunteers and the acquisition of small pots of funding to survive. This imbalance in size, values and resources affects my and other people's personal experience of working with universities. Therefore, I often wonder how both can possibly coexist in the same space without diminishing their inherent values and principles. How can universities see community-based organizations as integral? What do both organizations have to change to foster a more equitable working practice?

There are so many questions I am intrigued to investigate about the Imagine project and the co-production process with community partners, social enterprises, organizations and individuals. Exploring what is happening beneath the surface of the success of Imagine really excites me. How do the universities involved in Imagine 
engage in open dialogue with their community partners? How do the universities reach out to minority projects? What is the co-production model that will encourage or enable more ethnic minorities and diverse projects to engage with future projects such as Imagine? How do leaders feel within these partnerships, both in the university and in the community? At what stage of the process were community partners, social enterprises and individuals engaged? What was the discussion that took place, particularly about organizational values, structure, leadership and authority? How is authority shared between partnerships? What were the discussions around the differences?

\section{Paul: How Imagine involved community partners}

These are essential questions that Imagine needed to address in its outputs and publications. Much of the discussion about values, structure, leadership and authority took place in the 18 months before the grant was awarded during a complex application process, but discussion then developed during the running of the project. The core document for Imagine is its 'case for support' - a dense document that formed the basis on which the funder made decisions. I was involved in developing the application only from three months before the final submission, but community partners from South Yorkshire, who had worked with Kate Pahl before, and many people connected to Boingboing in Brighton, who had worked with Angie Hart, and community partners in Newcastle and Coventry, who had worked with Sarah Banks, were involved in codesigning the projects. This process was not even across Imagine, so in the work package that deals with the democratic context of civic engagement there were fewer community partners, and organizations such as Kirklees Local TV were brought on board as the project developed, rather than when it was initiated.

Across Imagine, there were different ways of enabling open dialogue to address some of the questions you raise about authority, structure and leadership. Inevitably, the academics who were funded directly by the grant played the greatest role, through monthly meetings, and numerous emails and phone calls to plan directions and events. But there were also structures within each part of the project that enabled broader discussion, dialogue, shared examination of data and interpretation of data, including co-writing and publication. We hoped we were doing our best to ensure collaborative, participatory and inclusive methods, from collaborative ethnographical workshops, co-inquiry groups, writing retreats, conferences involving community speakers, and many informal processes. Many of these will be described and evaluated in our book, Co-Producing Research: A community development approach (Banks et al., 2019, forthcoming). We were always very conscious of resourcing community partner involvement adequately, paying for work done and time given, for example, even when it was often enthusiasm, interest and community imperatives that encouraged participation.

\section{Milton: Imagine and ethnic diversity}

In addition, as a community partner I have concerns about the diversity of the ethnic make-up of the Imagine project. On every occasion that I have attended Imagine and other Connected Communities events I have been the only African descendant attending and there have been very few visible faces of people from ethnic minority backgrounds. This should be a concern for Imagine's learning process and its legacy. I refer also to differences such as class, ethnicity, sexuality, race, disability, religion and 
faith. I believe the learning and what could emerge from discussions about diversity between universities and their community partners are paramount to the present and future success of university partnerships with community-based organizations. Failure to include people of Black, Asian and minority ethnic backgrounds at a strategic level right from the start could contribute to a lack of involvement of people with those backgrounds with university projects in the future, or of involvement with the Imagine project in its current state. At times, I felt that the universities operating in Imagine were functioning in a split manner with regard to their relationships with community partners at conferences. Positive aspects were that everything was really working well, and everyone was happy and celebrating their individual learning and collective achievements, and rightly so. Conversely, a key negative aspect was apparent to me, but perhaps not to others: I neither saw nor heard any nationally contextualized discussion of equality, inclusion, diversity and difference. There was a sense that forms of inequality were not discussed as if they intersected with each other, but rather that they were examined as if they ran in parallel. For example, on at least two occasions events were held during Ramadan, while issues of inequality elsewhere in society were discussed at the events. Ethnicity was an issue to be discussed sometimes, rather than to bear in mind at all times (Eddo-Lodge, 2017).

\section{Paul: Ethnic diversity and higher education}

I acknowledge your concerns here. We have talked about how important emotion and feeling are in research, and that applies also to the contexts in which research is undertaken. You and I have discussed how dispassionate and detached research processes are exclusive and excluding. Zanib Rasool, a key community partner in Imagine, has articulated this in her essay 'Emotions in community research' (Rasool, 2018). I think that Imagine is more broadly diverse than you suggest, but this only scratches the surface of the structural issues in higher education. The number of people of colour who are academics, and particularly those in senior research positions, remains pitifully low, with only the smallest efforts being made to address a deep-rooted problem. In 2011/12, there were only 85 Black professors out of 16,000 professors in the UK. In 2015, only 1.59 per cent of academic staff were Black, and there were no Black academics in top roles in universities (HESA, 2017; Adams, 2017; Bhopal, 2017). Similarly, there were very few academics of Black, Asian and minority ethnic backgrounds involved in Imagine. Discrimination holds down the numbers of academics of minority ethnic background, and this is reflected in the Imagine academic team, but the project includes work with people from ethnic minorities at its core in Rotherham, Huddersfield and Coventry. The challenge was to ensure that this enabled participation at a strategic level in Imagine. There is some evidence for this, such as in the work package on culture based in Sheffield, which has shifted more and more to issues of ethnicity, considering the temporary success of UKIP in Rotherham, the child sexual exploitation crisis and street racism after the Brexit referendum. The potential for increased dislocation, ethnic inequalities and injustices exists especially in the transition towards Brexit, which has created uncertainty about the future and powerlessness (Mejias and Banaji, 2017), and I hope we have responded proactively to this change in context. Some key parts of Imagine have examined the experience of people of colour in community development. For example, Imagine Hillfields explored alternative narratives of life under regeneration in a poor area of Coventry, and in Rotherham, ethnicity has been at the core of the co-production of research and co-writing emerging from Imagine. But I agree that Imagine was interested in co- 
production, and often ethnic, gender and class inequalities were framed by how we explored co-production as an approach. We as academics tended to hold on to the power in this regard. Ultimately, we made the decisions about themes and issues to explore at Imagine events.

\section{Milton: Difference}

Imagine is seeking to envisage different futures and make them happen by encouraging the groups it works with to think about how they can change things in practical and hopeful ways, but there is little evidence of suggestions to build a continuous sustainable platform for community-based organizations or social enterprises to celebrate the success of their projects. Your response, Paul, seems quite reactive, addressing the situation as it is, rather than thinking about how to change the structural inequity. What will be Imagine's legacies? Imagine provides very few opportunities at its annual events (see www.imaginecommunity.org.uk/category/events) for organizational community leaders to express, from their perspective, how any of the projects were working or to explain any challenges or improvements that could be made vis-à-vis the leadership of the universities. What can community-based organizations bring to universities to foster and enhance effective and sustainable partnerships?

The failure to discuss or mention the aspect of difference in any depth was a big surprise to me at Imagine conferences and other Connected Communities events. I felt that the universities unconsciously and collectively took a superior position in the communication process at the Imagine conferences in preference to embracing and struggling with what makes the institutions or individuals feel uncomfortable when discussing the dynamics of difference. Some events and projects work more successfully than others: Boingboing, which describes itself as 'a mixed bag of people - academics, parents, young people, practitioners and service users - who find the idea of resilience useful in our lives and in our work', always put community partners at the front (Boingboing, 2018: n.p.). I have seen aspects of some of the points I am raising addressed implicitly in all the four areas of work within the Imagine project. The University of Brighton model, and their community partnership with Boingboing, seems to be an effective model from which universities and community partners might learn. They appear to work hand in hand, seamlessly, and with everyone being positive and committed to the project. Yet elsewhere, there seems to be a resistance to discuss issues that may challenge the universities' or individuals' values, principles and institutional objectives around equality, diversity and inclusion. I have struggled with this both personally and professionally. How can I find the key communication skills to discuss these issues effectively, without those who have the power and influence for change feeling that they may compromise their personal and professional integrity?

\section{Paul: Structural issues and responses}

The disquiet over the ethnic composition of university lecturers and managers has been growing steadily. A number of organizations and campaigns have highlighted the scandal of the number of Black professors and other academics (Ackah, 2014). There have been student-led campaigns, including Why Isn't My Professor Black?/ Why Is My Professor White? and Why Is My Curriculum White? (UCL, 2014). These emerge from the continuing shocking under-representation of Black academics in universities, and from global campaigns such as Black Lives Matter and Rhodes Must Fall. In the UK, the Runnymede Trust has published 'The visible minority: Nowhere to 
be seen in the academy' by Patrick Johnson (2015). The support/activist group Black British Academics has been established (http://blackbritishacademics.co.uk) and there have been some glimmers of change and hope, such as the establishment of the first Black Studies course in Europe, at Birmingham City University, under the direction of Kehinde Andrews (www.bcu.ac.uk/courses/black-studies-ba-hons-2017-18). As a result of the Connected Communities programme that funded Imagine, the AHRC established Common Cause: 'To begin to create a dynamic and evolving map of university-Black and minority ethnic community research and collaborations across the Arts and Humanities' (Common Cause Research, 2017: n.p.). But these glimmers reveal the scale of the problem rather than the beginnings of transformation. Almost every week, conscious and unconscious discrimination and resistance to equality come to light. When I was writing this section, the largest history festival in the United Kingdom defended itself against criticism that of its 150 speakers, only one was of a minority ethnic background (Olusoga, 2017). All academics need to think about issues of equality, diversity and representation in universities, not in passing or when it comes up on a committee agenda, but as part of the day-to-day activities of their departments, their research and their teaching. But I think also that they will need some encouragement and pressure to make this happen.

About a continuous stable platform for community-based organizations, I agree wholeheartedly. There are some models at some universities, so I think it is noticeable that the universities of Brighton and Sheffield (among many others) have clear public engagement strategies. The National Co-ordinating Centre for Public Engagement, which helps universities and the public engage with each other, provides resources to support all higher education institutions (NCCPE, 2018). Internationally, there is the Talloires Network, a global network of community-engaged universities, 'committed to strengthening the civic roles and social responsibilities of higher education' (http://talloiresnetwork.tufts.edu/who-we-are). Goddard (2009) has argued that universities need direct encouragement and reward to become 'civic universities'. At the moment, they secure funding for recruiting students and for research, but there is no premium for public engagement (although there is a premium for showing that research has 'impact' that can be measured by the Research Excellence Framework).

Of course, it could be further argued that for communities, there is something of a postcode lottery. The extent to which community-based organizations will be supported depends on the universities in the vicinity. But universities are complex and there is often a lack of clear information about how to gain support and who to contact. University websites flood the viewer with information, but at the same time give little away to those who are not in the know about how universities are organized. There is also another lottery of finding academic or administrative staff who will respond positively, or at all, to community organizations. Universities as large corporations are often best equipped to deal with other institutions that resemble themselves - the big galleries, museums and so on (although austerity has undermined them) - which are largely staffed by people who resemble themselves socially and ethnically.

\section{Milton's conclusion}

I would like to see a stronger commitment from the universities within the Imagine project in terms of ensuring that whatever the outcomes may be, there will be a model of good practice that emerges. That model must ensure that diversity, inclusion and difference are discussed and communicated much more as a matter of good practice and to the highest standard of ethics. Clearly, the private, public 
and voluntary sectors have different styles of working. What I have heard, seen and felt during my Imagine project experience is that sometimes these styles diametrically and fundamentally oppose one another. I would like to see more discussion around organizational expectations, leadership, authority in decision-making, and values and ethics in relation to how organizations can coexist in the same space without feeling their leadership or organizational integrity is being compromised. Finally, I believe that some form of structure could be created that could act as a 'revolving door', that is, offering community-based organizations an opportunity to have continuous dialogue with universities on how partnerships can survive beyond their project funding. I hope these suggestions will be discussed at future meetings and conferences, and that the excellent progress of Imagine continues and becomes even more enriched with good practice for our multicultural partners from wider and diverse backgrounds.

\section{Paul's conclusion}

I see that there is much to be done, both in terms of foregrounding discussions of ethnic diversity in universities and in ensuring universities understand the needs of community organizations. I accept and value your critique and it emphasizes why academics must research with, and listen to, community partners. As quickly as possible, universities need to address issues of ethnic disparity in appointments and promotions (recognizing that these have not happened accidentally). Numbers of undergraduate students of Black, Asian and minority ethnic backgrounds are proportionate to the population at large, but Black students, in particular, attain first class and upper second-class degrees less often than White students with similar A levels (Ethnicity Facts and Figures, 2018; ECU, 2018). Numbers of postgraduates of Black, Asian and minority ethnic backgrounds need to increase, and initiatives are needed to guide them through to permanent posts in universities. In addition, academic staff need sufficient training for collaborative research activities, and collaborative research outcomes need to be rewarded. At the moment, individualism reigns. Universities' priorities remain their own sustainability through student recruitment, grant capture and other income-generating activities, which places emphasis on key performance indicators rather than social contribution. Our conversation has emphasized to me the negative impact such priorities have on people such as you, who seek to develop their communities in towns and cities where universities are located. Here are very large institutions that could make substantial contributions to the localities in which they are situated, if they are held to account and if they empower academic staff to undertake such activities. This has to be done through continuing partnerships such as ours, where we can talk, and disagree, but seek ways forward to make change.

\section{Towards agreement}

We agreed that to achieve equitable partnerships that take account of resource inequalities, university leaders (and academics) need better understanding of community groups and their modes of practice. There is clearly a need for university staff to have time for training and reflection on the university's role in relation to the communities in which it is located. It is not always easy for academics working fifty-hour weeks to have time to think about how their research might be useful, so the more guidance provided the better. There also need to be more visible access points (and support from senior management teams) in order that those outside the university can find their way into the appropriate place. This might mean that universities could have a regular space for 
community organizations to share celebrations and challenges. This should be linked to an open mapping of university structures, so that community organizations find the right people and are then able to present the appropriate message.

But on the other side, community organizations need to have a level of skills and knowledge to enable them to negotiate with universities. Such expertise exists in many business and larger cultural organizations. Universities could provide training for how community-based organizations can work with universities, as well as open days organized by the university to encourage and prepare small organizations for their encounter with the big corporate bodies that universities are. Such meeting points have many advantages, including the greater visibility of the ethnic inequalities within the universities on the one hand, and a recognition of diversity outside the university on the other. Universities need to address issues of structural discrimination, and that is easier if it is clearer to all people that universities have a problem. Budd Hall (2016: 24) has argued that to move towards knowledge democracy there also needs to be 'recognition of the knowledge generating spaces outside the academy', but also that community organizations need to be able to access research funding to strengthen their voices. There are, then, some take-home points from our conversation. The role of universities, including the means by which they can be embedded within the communities in which they are located, needs exploring further. There are many models, from the civic to the engaged university. But universities need to consider the needs of their external partners carefully - universities should not always put their own interests first, but should consider the mutual benefits and, sometimes at least, should give up power and authority to people from communities who have knowledge, skills and expertise about what they need. Individual academics, including me and others in Imagine and similar projects, also need to think about the power and authority they hold. They may feel disempowered by increasing workloads and increased bureaucratization of higher education, but they often have greater access to resources than they think and maintain some considerable autonomy over parts of their role. These can be used to enable research partnerships with those outside universities. Within Imagine, there is room for greater discussion of what comes afterwards as the end of the five-year project has been reached. How do we ensure, together, that all those who have taken part are provided with support for the next steps in community development and the co-production of research? There is not an easy answer, but there is a conversation to be had.

\section{Notes on the contributors}

Milton Brown is Chief Executive of Kirklees Local TV, which documents stories in Huddersfield and Dewsbury and surrounding areas. He is undertaking a PhD at the University of Huddersfield on the experience of African-Caribbean people in navigating identity in post-war Britain.

Paul Ward is Professor of Public History and Community Heritage at Edge Hill University in Ormskirk, Lancashire. Before that, he worked at the University of Huddersfield, teaching and researching British national identities and the co-production of historical knowledge.

\section{References}

Ackah, W. (2014) 'There are fewer than 100 black professors in Britain - why?'. The Conversation, 10 March. Online. https://tinyurl.com/y7xkrvjj (accessed 4 November 2018). 
Adams, R. (2017) 'British universities employ no black academics in top roles, figures show'. The Guardian, 19 January. Online. https://tinyurl.com/y7trk5fk (accessed 4 November 2018).

Banks, S. Hart, A., Pahl, K. and Ward, P. (eds) (2019, forthcoming) Co-Producing Research: A community development approach. Bristol: Policy Press.

Bhopal, K. (2017) 'Addressing racial inequalities in higher education: Equity, inclusion and social justice'. Ethnic and Racial Studies, 40 (13), 2293-9.

Boingboing (2018) 'Our story'. Online. https://www.boingboing.org.uk/about-us/story (accessed 5 November 2018).

Common Cause Research (2017) 'The project'. Online. www.commoncauseresearch.com (accessed 8 June 2018).

Connected Communities (2016) 'About'. Online. https://connected-communities.org/index.php/ about (accessed 8 June 2018).

de Sousa Santos, B. (2016) 'Epistemologies of the South and the future'. From the European South, 1, 17-29. Online. https://tinyurl.com/yayzdvf3 (accessed 4 November 2018).

ECU (Equality Challenge Unit) (2018) 'Degree attainment gaps'. Online. https://tinyurl.com/ hwg5gq5 (accessed 4 November 2018).

Eddo-Lodge, R. (2017) Why I'm No Longer Talking to White People about Race. London: Bloomsbury Publishing.

Ethnicity Facts and Figures (2018) 'Entry rates into higher education'. Online. https://tinyurl.com/ ya4cuhwz (accessed 4 November 2018).

Facer, K. and Enright, B. (2016) Creating Living Knowledge: The Connected Communities Programme, community-university relationships and the participatory turn in the production of knowledge. Bristol: University of Bristol / AHRC Connected Communities.

Fallis, G. (2014) 'Reclaiming the civic university'. Academic Matters, June, 3-6. Online. https://tinyurl.com/ybartdbm (accessed 4 November 2018).

Giroux, H.A. (2013) 'Public intellectuals against the neoliberal university'. Truthout, 29 October. Online. https://tinyurl.com/yakvq82q (accessed 4 November 2018).

Goddard, J. (2009) Reinventing the Civic University. London: NESTA.

Hall, B.L. (2016) 'Towards a knowledge democracy movement'. In Evans, R., Kurantowicz, E. and Lucio-Villegas, E. (eds) Researching and Transforming Adult Learning and Communities: The local/global context. Rotterdam: Sense Publishers, 15-26.

Hall, B., Jackson, E., Tandon, R., Fontan, J.-M. and Lall, N. (eds) (2013) Knowledge, Democracy and Action: Community-university research partnerships in global perspectives. Manchester: Manchester University Press.

Hall, B. and Tandon, R. (2015) 'Are we killing knowledge systems? Knowledge, democracy and transformation'. Online. www.politicsofevidence.ca/349/ (accessed 8 June 2018).

HEFCE (Higher Education Funding Council for England) (2016) 'REF impact'. Online. www.hefce. ac.uk/rsrch/REFimpact (accessed 8 June 2018).

HESA (Higher Education Statistics Agency) (2017) 'Staff at higher education providers in the United Kingdom 2015/16'. Online. www.hesa.ac.uk/news/19-01-2017/sfr243-staff (accessed 8 June 2018).

Johnson, P. (2015) 'The visible minority: Nowhere to be seen in the academy'. In Alexander, C. and Arday, J. (eds) Aiming Higher: Race, inequality and diversity in the academy. London: Runnymede, 13-14.

Kirklees Local Television (2016) Imagine [video]. Online. https://tinyurl.com/y85owm7p (accessed 4 November 2018).

Mejias, S. and Banaji, S. (2017) UK Youth Perspectives and Priorities for Brexit Negotiations: Report for the All Party Parliamentary Group on a Better Brexit for Young People. London: London School of Economics and Political Science.

NCCPE (National Co-ordinating Centre for Public Engagement) (2018) 'We help universities engage with the public'. Online. www.publicengagement.ac.uk (accessed 17 November 2018).

Nolan, M., Hanson, E., Grant, G., Keady, J. and Magnusson, L. (2007) 'Introduction: What counts as knowledge, whose knowledge counts? Towards authentic participatory enquiry'. In Nolan, M., Hanson, E., Grant, G. and Keady, J. (eds) User Participation in Health and Social Care Research: Voices, values and evaluation. Maidenhead: Open University Press, 1-13.

Olusoga, D. (2017) 'Enough of the old excuses for whites-only history'. The Guardian, 25 June. Online. https://tinyurl.com/y9pkg6tz (accessed 4 November 2018).

Pace, I. (2018) 'The RAE and REF: Resources and critiques'. Desiring Progress blog, 3 April. Online. https://tinyurl.com/y8du7e3g (accessed 4 November 2018). 
Partnerships for the SDGs (2017) 'UNESCO Chair in Community Based Research and Social Responsibility in Higher Education'. Online. https://tinyurl.com/y889zxc4 (accessed 4 November 2018).

Rasool, Z. (2017) 'Collaborative working practices: Imagining better research partnerships'. Research for All, 1 (2), 310-22.

Rasool, Z. (2018) 'Emotions in community research'. In Campbell, E., Pahl, K., Pente, E. and Rasool, Z. (eds) Re-Imagining Contested Communities: Connecting Rotherham through research. Bristol: Policy Press, 115-22.

Shortt, N.K. (2016) 'Is it time to reconsider the impact agenda?'. CRESH blog, 8 July. Online. https://tinyurl.com/yay9ayp3 (accessed 4 November 2018).

Smith, L.T. (2012) Decolonizing Methodologies: Research and indigenous peoples. 2nd ed. London: Zed Books.

UCL (University College London) (2014) Why is My Curriculum White? [video]. Online. https://tinyurl. com/p3nf5h2 (accessed 4 November 2018).

UK Research and Innovation (2018) 'The social, historical, cultural and democratic context of civic engagement: Imagining different communities and making them happen'. Online. https://tinyurl. com/y8lhzals (accessed 4 November 2018). 